\title{
TOWARDS AN INITIATIVE-BASED INDUSTRY 4.0 MATURITY IMPROVEMENT PROCESS: MASTER DRILLING AS A CASE STUDY
}

\author{
G.J. Maasz ${ }^{1 * \#} \&$ H. Darwish ${ }^{1}$
}

\section{ARTICLE INFO}

\section{Article details \\ Presented at the $29^{\text {th }}$ annual conference of the Southern African Institute for Industrial Engineering (SAIIE), held from 24-26 October 2018 in Stellenbosch, South Africa \\ Available online \\ Contact details \\ Corresponding author \\ Gmaasz@masterdrilling.com \\ Author affiliations \\ 1 Department of Industrial Engineering, North West University, South Africa \\ \# The author was enrolled for an MEng (Industrial) degree in the School for Industrial Engineering at the North West University, South Africa}

DOI

http: //dx.doi.org/10.7166/29-3-2052
ABSTRACT

Industry 4.0 is an unavoidable global revolution with disruptive effects. Many sectors in South Africa are currently underprepared for the transformation that is necessary to stay competitive. An ever-present need therefore exists for the country to stay relevant in the global industry. The mining sector consists of different companies that contribute to the sector in its entirety. There is major potential as long as this Industry 4.0 wave is properly leveraged and its technologies are integrated into the operations of this sector. To use emerging opportunities fully, areas of weakness in the sector should be identified and appropriately addressed. This article takes a different approach to understanding mining sector readiness by analysing a company in the sector. A case study is done at Master Drilling to identify possible areas of weakness and potential, focusing on Industry 4.0 initiatives. This is further enforced, for Industry 4.0 , by using a Threats, Opportunities, Weaknesses, Strengths (TOWS) analysis on the company. An Industry 4.0 maturity analysis is conducted to identify the areas needing further investigation. A process is created to enable any entity to analyse its maturity, providing an approach that leads to areafocused technology innovations in that company.

\section{OPSOMMING}

Industrie 4.0 is 'n onvermydelike globale rewolusie met ontwrigtende effekte. Baie sektore in Suid-Afrika is tans onvoorbereid vir die nodige transformasie om mededingend te bly. Daar bestaan ' $n$ ewigdurende behoefte vir die land om relevant te bly binne die globale industrie. Die mynbou sektor bestaan uit verskillende maatskappye wat tot die sektor in sy geheel bydra. Daar is groot potensiaal mits hierdie Industrie 4.0 golf behoorlik geïntegreer en aangewend word binne hierdie sektor. Om Industrie 4.0 geleenthede ten volle te benut, moet areas van swakheid binne die sektor geïdentifiseer en aangespreek word. Hierdie artikel neem 'n unieke stap in die begrip van mynbousektor gereedheid deur ' $n$ maatskappy binne die sektor te analiseer. 'n Gevallestudie word gedoen by Master Drilling. Dit identifiseer moontlike areas van swakheid en potensiële fokus op Industrie 4.0 inisiatiewe. Dit word verder aangevul deur 'n bedreigings, geleenthede, swakhede en sterkpunte-analise op die besigheid aangaande Industrie 4.0. 'n Industrie 4.0-volwassenheidsanalise word uitgevoer om die gebiede van verdere ondersoek te identifiseer. ' $n$ Proses is ontwerp om enige entiteit in staat te stel om sy volwassenheid te analiseer, wat area-gefokusde tegnologie innovering tot gevolg kan hê. 


\subsection{Introduction to context}

Global industry has been advancing in technologies and innovation since the 1760s [1]. Industries are moving beyond the mass production periods, and are entering a customised production era. Industry 4.0 aims to enhance the capability of a company to cater to the different needs of its customers by using various disruptive technologies [2]. These technologies include the Internet of Things, smart manufacturing, artificial intelligence, big data, and machine learning, among others. A central requirement underpinning Industry 4.0 is autonomous machinery that can interact with objects and people through its digital twin [2].

The increasing complexity brought by the wave of Industry 4.0 creates uncertainty about the capacity and capabilities necessary for companies and sectors to adapt [3]. South Africa's industry has been slower to adopt new technologies [4]. Yet the potential is there to adapt and, possibly, even to leapfrog global competitors. The South African automotive industry has shown more improved adoption to Industry 4.0 technologies than any other sector in the country [4]. There is, however, a lack of successful technology adoption in the mining sector, which is mainly due to the lack of internet connectivity, communication technology, and accessibility to these technologies on site [4].

\subsection{Background on the mining industry}

Mining in South Africa is a very labour-intensive, time-consuming, and expensive exercise due to the low optimisation levels of current practices. Global technologies, such as large tunnel bores, drone surveying, and other automated machinery, have not been a priority for local mining companies, and are increasingly more difficult to obtain due to decreases in profits over the years - in turn, the result of the capital required to acquire and adapt to these technologies.

The mining industry in South Africa contributes roughly 5.4 per cent of the country's gross domestic product (GDP), having decreased by about 15 per cent since the 1980 s (when it constituted 21 per cent of the GDP) [5]. The industry employs over 450000 individuals, or 2.7 per cent of the South African working population [6]. Market capitalisation decreased by 25 per cent from 2017, and investors in this sector are receiving decreasing dividends [6]. The potential for improvement and expansion is present, as the technologies are becoming more readily available. Yet it is often thought that the South African mining industry has little to no use for Industry 4.0 because of the remoteness of the operations and the strict regulations being enforced that limit the use of technology underground. This is further influenced by financial limitations, such as the decreasing market capitalisation and currency value in the country.

\subsection{Examination of the Master Drilling case study}

Master Drilling, a world leader in specialised drilling solutions [7], functions not just in the South African mining industry, but globally. About 25 per cent of the company's revenue is generated in South Africa, where its head office is located. The company was founded in South Africa, and has increased its global footprint over the years.

Being at the forefront of the raiseboring industry, it is imperative for Master Drilling to innovate and implement the best possible practices and technologies to increase its global performance. Using technology for strategic advantage is one of the foundational blocks of Kobayashi's 20 keys to workplace improvement [8]. This creates potential for the use of Industry 4.0 technologies, referred to in Section 3.1. Master Drilling has recently finished developing a mobile tunnel bore that aims to increase the speed at which excavation can be done by 300 per cent. This could remove the need to blast tunnels with explosives. The tunnels thus created are circular, producing a more stable structure than that of the current square-shaped ones created by explosives. This is one of the many ways in which Master Drilling is contributing to the sector, changing it for the better. 
Innovation and disruptive technologies have a major role to play in the South African mining context. The focus throughout the article is kept on recognising the gaps in the mining industry by investigating Master Drilling's Industry 4.0 readiness. Various technologies and different maturity models are discussed that unpack the readiness of Master Drilling to adopt Industry 4.0. The research framework is summarised in Fig. 1, and the research problem and questions are formalised. The objectives that are derived from the research questions are also listed. Everything in the article sets the groundwork for developing an initiative-based Industry 4.0 improvement process that will initially be applied at Master Drilling, but with the potential to be broadened to the sector.

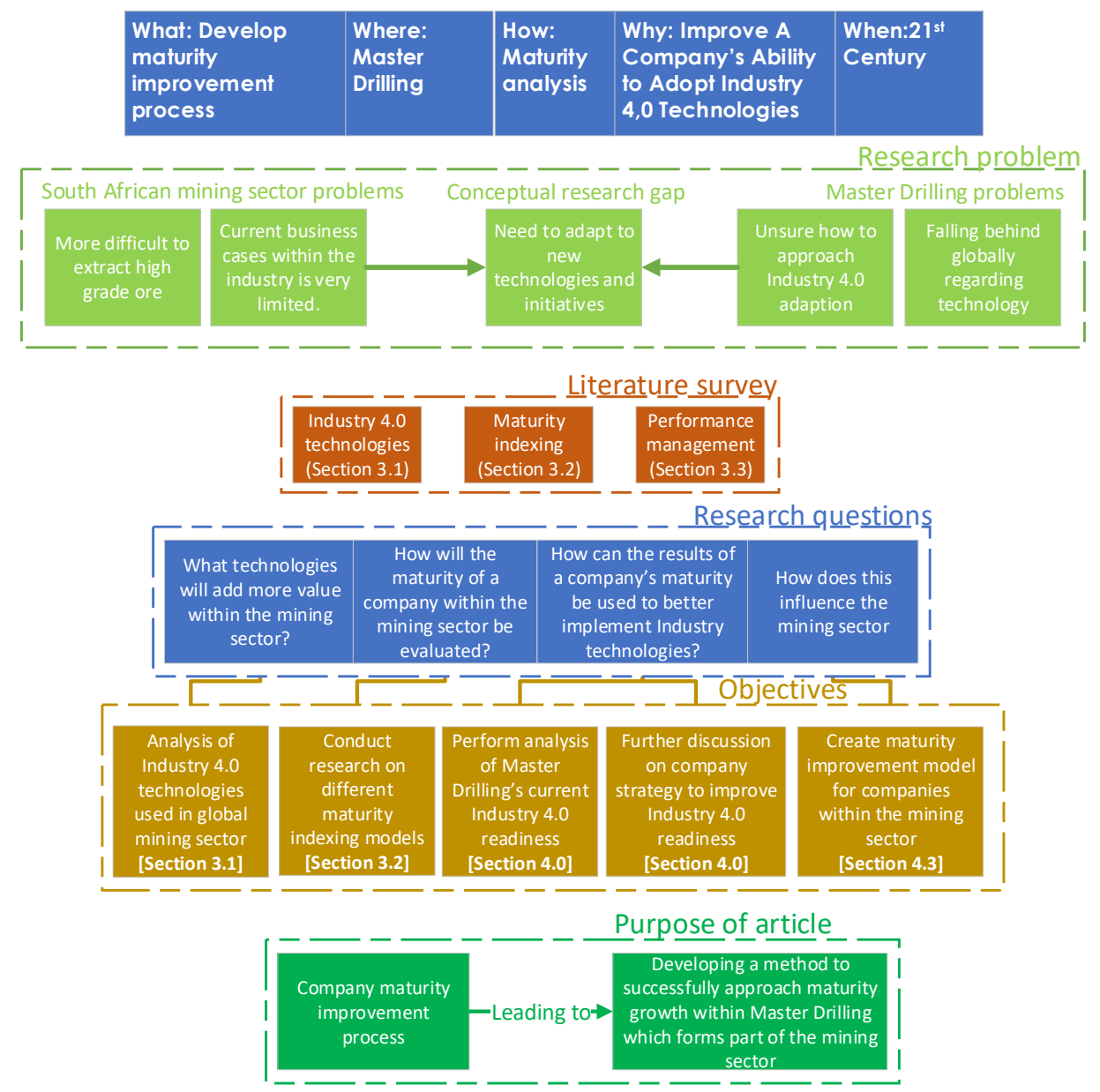

Figure 1: Research framework

\subsection{Methodology}

Locating the strengths and challenges in a company in the industry itself can lead to better areafocused technology innovations, not only in a company, but also in the industry. To determine the areas to which the focus should be switched in the industry, a case study is done on Master Drilling. Using the IMPULS readiness self-check analysis [9], the organisational maturity of Master Drilling regarding Industry 4.0 readiness is determined for six different dimensions. Seven high-ranking individuals in the organisation completed the analysis to reveal the company's as-is maturity, and identify its areas of weakness and its areas of potential. A further focus is then placed on two of the areas that could lead to optimised operations in the business. It is worth noting that successful technological improvements in the company can lead to a quicker adoption of Industry 4.0 initiatives for the entire industry. The study leads to the creation of a maturity improvement process for Master Drilling that aims to mature it with regard to Industry 4.0 initiatives and technologies. 


\subsection{Technology}

"Through a virtuous cycle-technological improvement enabling innovation, which in turn serves as a platform for further technological improvement and innovation-exponentially advancing technologies lead to exponentially accelerating innovation. For companies, this accumulation of technological advances, and the consequent layering of innovation upon innovation, can pose the threat of disruption-but can also open the door to great opportunity. And the technologies show no sign of stabilizing." [10]

This lays a foundation for the global macro-evolution of industries due to technological innovations and improvements. Technologies such as the Internet of Things, machine automation, big data, virtual reality, and augmented reality open a new world to the automation of processes and the improved collaboration of man and machine. The automation of machinery in any sector creates an environment of sustainable constant outputs with extremely high accuracies that are not dependent on emotions, physical capabilities, or even academic background. These disruptive technologies can be useful in any business sector if implemented correctly, but require a set of skills for, and knowledge of, the subject. Technology advancements in any company are dependent on the company's maturity to accept the improvements and implementations.

\subsubsection{Internet of Things (loT)}

The Internet of Things is where sensors and actuators embedded in physical objects communicate via data transfer over a wireless and wired network connected to the Internet [11]. Enormous amounts of data can be sent through these physical devices, creating opportunities for intensive data analytics and reporting. McKinsey \& Company identified six types of applications, in two broad categories, that are emerging from this trend of the Internet of Things [11]. The two broad categories are:

1. Information and analysis

a. Tracking behaviour: monitoring behaviour of objects over time.

b. Enhanced situational awareness: achieving real-time awareness of the physical environment.

c. Sensor-driven decision analytics: assisting human decision-making through deep analysis and data visualisation.

2. Automation and Control

a. Process optimisation: automated control of closed systems.

b. Optimised resource consumption: control of consumption to optimise resource use across network.

c. Complex autonomous systems: automated control in open environment containing great uncertainty.

A successful example from the mining industry can be seen in a company called Hard-Line, which remotely controls heavy machinery in mining and other industries [12]. This creates a safe and healthy environment for the operator, which leads to higher employee satisfaction and better operational utilisation. According to Eric Croeser, Partnerships Director of loT.nxt, the use of IoT can protect jobs in the sector, as well as the lifespan of mining operations [13]. The use of loT creates increased capabilities for new business models and automated processes.

\subsubsection{Machine automation}

The use of automated machinery could replace 45 per cent of work activities using technology that had been developed by the year 2015 [14]. This includes all wage classes in the economy, resulting in a significant improvement in routine hard-labour activities. Even though this did not happen, the above fact stresses the opportunity of technology advancements that could have been made three years ago - not to mention the potential of current available technologies. McKinsey Quarterly states that about 20 per cent of a CEO's working time could be saved by automating certain functions [15]. This creates the capacity for individuals to spend time on more value-adding activities rather than on repetitive day-to-day activities. This leads to the redefinition of jobs, and the transformation and increased optimisation of business processes [15]. This does not, however, mean the substitution of employees; rather, it creates value without associating it with labour-based 
activities. Workers must work alongside machines, but will also need to transform [16] with regard to their knowledge, independent learning skills, and ability to stay up to date with global technology trends.

Labour-dependent activities, such as those in the mining industry, create various uncertainties and decreased productivity throughout the working day. They contain large risks, as people's lives and health are at risk. German mining machine manufacturer GHH Fahrzuege recently developed an autonomous underground loader on which research is being done in a mine in Chile [17]. The currently available automating technology is creating new horizons in the industry. Automation practices in industry are a threat to labour-intensive operations, as machinery has the potential to replace the jobs of some individuals. It is, however, an opportunity to improve operations in all industries.

\subsubsection{Big data}

Most activities in life create some form of data that, if used correctly, can be valuable in certain situations. Data creates the ability for people to make more informed decisions, using evidence, instead of relying on intuition [18]. Big data refers to the concept of a large administrationorientated database that is used to add value to an entity [19]. Big data only creates value when the massive amounts of data that are stored are used in some way or another to add value to those for whom it is captured.

To capture and store huge amounts of data is costly in most situations, which also creates the difficulty of analysing such vast amounts of data to extract useful information. When used correctly, data can lead to countless improvements, such as:

- Improved preventative maintenance

- $\quad$ Product and customer trends

- $\quad$ Product lifecycle analysis

- Population generalisations

These are only a few of the improvements that can be made by using big data technology. Outcomes, described as increased overall financial performance and optimised business prioritisation [20], can be produced using big data.

Big data is used by the predictive maintenance company Dingo on equipment from all sectors. They have generated over US\$450 million in cost savings using their solutions in real-life applications [21]. Data and software initiatives hold major potential for optimisation in the industry. The benefit of big data in the mining industry is debatable; but while it currently offers only financial value, opportunities must still emerge where it increases the effectiveness with which mining operations take place. Big data databases can store massive amounts of data, which poses a security threat to confidential data, as databases can be breached.

\subsubsection{Virtual reality (VR)}

VR is different from augmented reality in the sense that it digitally immerses the user in a virtual environment, instead of digitally inserting an object into the user's physical environment. This is done by using special glasses, or similar devices, that cover the user's vision, creating the 3D environment in which the user is then placed. Widely used applications in which this technology is effective are:

- The military

- Education

- Entertainment

- Sport

Users have first-hand experiences without entering the field, assisting with planning and various other tasks. Data is produced with this technology, which in turn is used to develop training methods, communication, and interaction methods [22]. The technology is, however, limited by the environments that are created and displayed via the hardware.

At the University of Pretoria, a VR system is used to train and educate both students and mine staff on mine safety and similar topics [23]. This is done by immersing the user in a simulated mining 96 
environment. The use of VR in training has countless applications because of the exposure it creates for the user while removing all safety risks from the exercise. Mining operations can become a lot safer and more satisfactory for miners if combined with the use of VR and loT. This technology is an opportunity for training practices in Master Drilling.

\subsubsection{Augmented reality (AR)}

This refers to the practice of taking $3 \mathrm{D}$ virtual objects and inserting them into the user's immediate environment [22] by using digital smart devices, such as smartphones or smart glasses. The smart image or 3D object is visualised in the user's current environment. It creates the opportunity for the user to view the object from different angles, and potentially to see the effect of the object in the real environment before it is physically placed in the environment.

Although countless more exist, current AR business applications are found in the following environments:

- $\quad$ Advertising: using your GPS location, a smart device augments your environment by displaying different services around you, such as restaurants, entertainment, etc.

- Military: a transparent heads-up display (HUD), is positioned in front of the user's vision, containing data such as altitude, airspeed, and horizon line.

- $\quad$ Medical: used to practise surgery without the risk of injuring somebody. It can be combined with MRI and X-ray scans for the surgeon to use as guidance in an operation.

- Navigation: users can see the navigation view directly in front of a car via the smart device.

- Maintenance: using a headset, the user can see visually represented data on a machine or asset in need of maintenance. The zone or parts in need of maintenance are highlighted or illuminated with specific colours.

All applications of this specific technology, in these environments, improve how the user will perform, be it for personal or corporate use. It is also necessary for the AR smart device to be linked with some sort of database via loT.

NORCAT, a global leader in the development of skilled labour training, recently unveiled multiple VR learning technologies aimed at training in the mining industry [24]. This creates a vast potential for how training can both be approached and successfully delivered to individuals. The use of AR in mines is minimal, which brings into question the value of its improving operations efficiency and effectiveness. It is, however. a good supporting tool to be used for marketing and training purposes.

\subsection{Maturity indexing}

Industry 4.0 entails the vertical and horizontal integrations of IT systems in all stages of a company's value chain. For this to be achieved, the maturity of current technology and information architecture must be evaluated [25], accompanied by the level of maturity that the company desires to achieve. This can be done using various tools and maturity index models, all of which constitute the analysis of a company's ability to integrate Industry 4.0 technologies effectively into its current business structure.

\subsubsection{Acatech STUDY: Industrie 4.0 Maturity Index [26]}

This maturity model gives guidance to companies for transformation to Industry 4.0 , using a sixstage model focusing on four different key areas. These stages are:
1. Computerisation
2. Connectivity
3. Visibility
4. Transparency
5. Predictive capability
6. Adaptability

The four areas in which each of these stages are focused are:
1. Resources
2. Information systems
3. Culture 
4. Organisational structure

The study analyses each specific area, after which action plans are designed and implemented to produce growth in each. The output of a company that is mature in all these fields with regard to Industry 4.0 has a massive reduction in the time it takes to react to any event affecting the company. This study thus improves the reaction time of companies to incoming situations that could disrupt their business.

\subsubsection{IMPULS readiness self-check analysis [9]}

This readiness measurement model, commissioned by the IMPULS Foundation of German Engineering Federation, focuses on six different dimensions to evaluate the readiness of an entity to adopt Industry 4.0 initiatives. These dimensions are:

\section{Strategy and organisation \\ 2. Smart factory \\ 3. Smart operations \\ 4. Smart products \\ 5. Data-driven services \\ 6. Employees}

Questions are asked via an online questionnaire, and readiness levels are assigned as the answer to each question. These levels range as follows:

- Level 0, Outsiders: companies that have no plan to implement Industry 4.0 initiatives

- Level 1, Beginner: companies with introductory plans to implement Industry 4.0 initiatives

- Level 2, Intermediate: companies that have Industry 4.0 initiatives in place and have structures in place to facilitate further adoption

- $\quad$ Level 3, Experienced: organisations actively pursuing Industry 4.0 adoption and initiatives

- Level 4, Expert: organisations that have Industry 4.0 initiatives in place and are contributing to, and implementing, new technologies to improve their business models

- Level 5, Top Performers: leading the industry in Industry 4.0 innovation and implementation, while pursuing new technologies and actively contributing to the Industry 4.0 community

The results include an overview of the potential to adapt to Industry 4.0 initiatives in each of the above-mentioned dimensions on which the analysis focuses.

\subsection{Performance management}

Performance management helps organisations to achieve their goals [27] through managing the people and skills currently found in them correctly. Better use of, or improvement in, the current human factor in an organisation leads to the following:

- $\quad$ Company knowledge and experience not being lost

- $\quad$ Upskilling of individuals, creating higher job satisfaction [27]

- $\quad$ Ability better to accommodate changes in an environment

The role of the performance management of individuals in a company is aimed at achieving the company's strategic goals. When these goals are achieved, the company has a higher probability of success. Various models exist on the successful management of employee performance, but an alternative approach is feasible.

In-depth management of employee performance identifies skill gaps, if done correctly. Analysis of the performance areas where employees fall short reveals where the skills deficiency is located. Aligning employees' performance goals with the company's strategic goals ensures that expectations are met. These are summarised in Fig. 2. The company, in turn, must thrive financially in the sector in which it is located. 


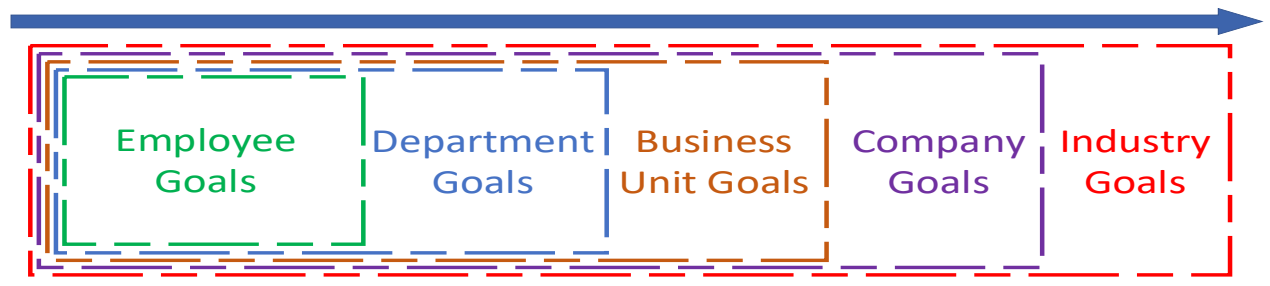

Figure 2: Alignment of employee goals with company goals [self-designed]

Performance management is a key factor in identifying skills gaps in any area of an organisation or individual. It is best approached through a top-down methodology, starting with the company's performance with regard to the set goals, and working downwards to find the resulting issue that led to the underperformance of a certain party. It is thus of great importance to link the goals of the company, all the way to those of the employee, to the company's Industry 4.0 strategy.

\subsection{Improvement models}

Previous work has been done on improvement models for the mining industry. A specific example, shown below in Fig. 3, is a methodology geared to modernising the mining industry by managing the introduction of technologies and initiatives [28]. This formed part of a Masters study that emphasises the importance of innovative initiatives and technologies in the South African mining sector. The study focused on analysing an innovation stage-gate model. Further research was done on the different key gate criteria, stage activities, and critical success factors [28].

The specific model shown in Fig. 3 uses best-practice stages and gates to focus further literature into each stage and gate [28]. This model is recommended for research and development work focused on the mining industry, and was evaluated in a case study where a missing person locator system was designed. This approach has been proved successful, but still has potential for refinement, as stated by the author's suggestions for further work, including holding workshops and applying experiential learning [28]. It is thus a valuable approach to consider when creating a cyclical model for continuous improvement in the mining sector of South Africa.

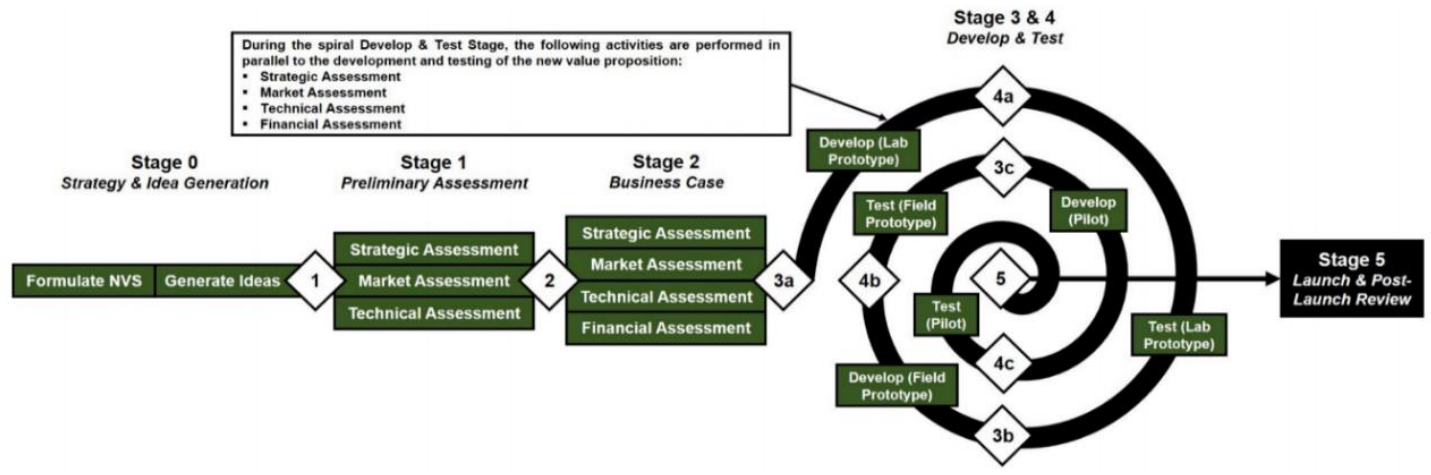

Figure 3: Stage-gate model for parallel activities and spiral development testing [28]

The model above can be especially helpful in forming the internal process in Master Drilling. However, the process being developed in this study requires a more cyclical approach, closing the loop between company improvements and those in the affected sector. It highlights the potential of more improvement opportunities arising as the different technologies of Industry 4.0 are implemented over time. This process is discussed in Section 4.3, which describes the approach of identifying areas of weakness and areas of potential. It further describes the use of the areas of potential to improve the areas of weakness.

\section{MASTER DRILLING CASE STUDY}

Master Drilling is a company in the global mining sector, with a focus on technology, that serves clients with a specialised drilling solution to fit their specific needs. The company's strategy focuses on their four strategic pillars [7]: 
1. Sustainable growth

2. Optimisation and increased profitability

3. Technology optimisation and development

4. People capacity and development

All four of these pillars focus on the development of the company and all its assets, both tangible and intangible. Having such a strong technology and development focus while situated in the mining sector, it is a prime company to use as a case study on the topic of the Industry 4.0 maturity of the sector itself. Although the company currently works on new and developing mines, their goal is to be the first point of contact for any customer looking to expand their current, or start new, mining operations. The next section focuses on how maturity indexing is used to identify the strengths and weaknesses in Master Drilling.

\subsection{Maturity indexing}

The IMPULS readiness self-check analysis was completed by seven high-ranking individuals in Master Drilling. This specific maturity indexing technique was selected, based on the quality of the research on which the questionnaire is built [29]. The quality and academic nature of the IMPULS readiness analysis was the reason it was selected as a suitable method for this study. The resulting data was consolidated, and is reported on in the rest of Section 4. The questions were forced-choice based, requiring the user to choose an answer between provided options. This was subject to the user's knowledge of the specific business area. This data reveals areas of potential in Master Drilling that are highly mature in Industry 4.0 readiness, as well as less mature areas. This creates the potential in the company to strengthen and improve the areas of weakness by using the company's areas of potential.

The two most mature dimensions found are the 'employees' and 'smart operations' dimensions, based on their having the highest maturity levels with the least deviation in their answers (see Fig. 4). This shows that both 'employees' and 'smart operations' in Master Drilling are competent enough to adapt to new improvement and disruptive technologies. By exploiting these, the weaker dimensions can be improved. The costly nature and current financial state of the mining industry requires all improvements to make financial sense over the long term, while still moving in the direction in which the company's strategy and vision are aimed. This turns the focus to those areas that have the greatest impact on a company's current state, rather than just those that are the weakest regarding Industry 4.0 readiness.

The test results reveal the level of maturity of each company dimension for Industry 4.0 readiness. The responses of all individuals who completed the survey is summarised in Fig. 4, in the form of a box chart. The resulting dimensions chosen for further discussion are 'employees' and 'smart operations', as these are the current strengths and resources available to Master Drilling with which the weaknesses can potentially be improved. The box plot shown in Fig. 4 displays the maximum, minimum, average, first quartile, and third quartile values from the management responses to the IMPULS readiness self-check analysis.

\subsubsection{Employees}

A further clarification of the adequacy of the company's employees is conducted, based on the strength of the company's executive management team. In Master Drilling, departments have DISC (dominance, influence, steadiness, conscientiousness) profiles that identify the strengths and weaknesses of the entire team [30]. The DISC profile displays an individual's response patterns when put into certain environments by using a forced-choice questionnaire method. An example of such a test is that of Thomas International -specifically, the Personal Profile Assessment. This evaluates a team in nine different roles, using three measuring descriptions [31]. An example of this is seen in the company's executive team, shown in Figure 5: Executive personality analysis. It identifies personality traits in the company that contribute to successful growth. 


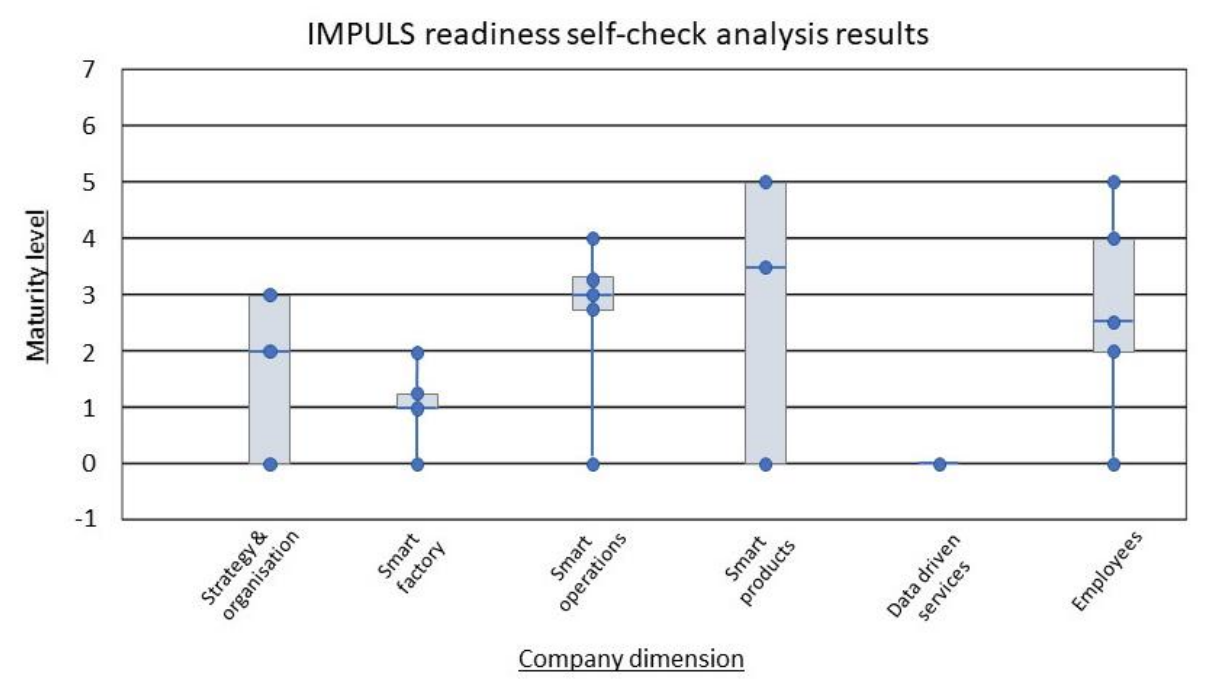

Figure 4: IMPULS readiness self-check analysis results

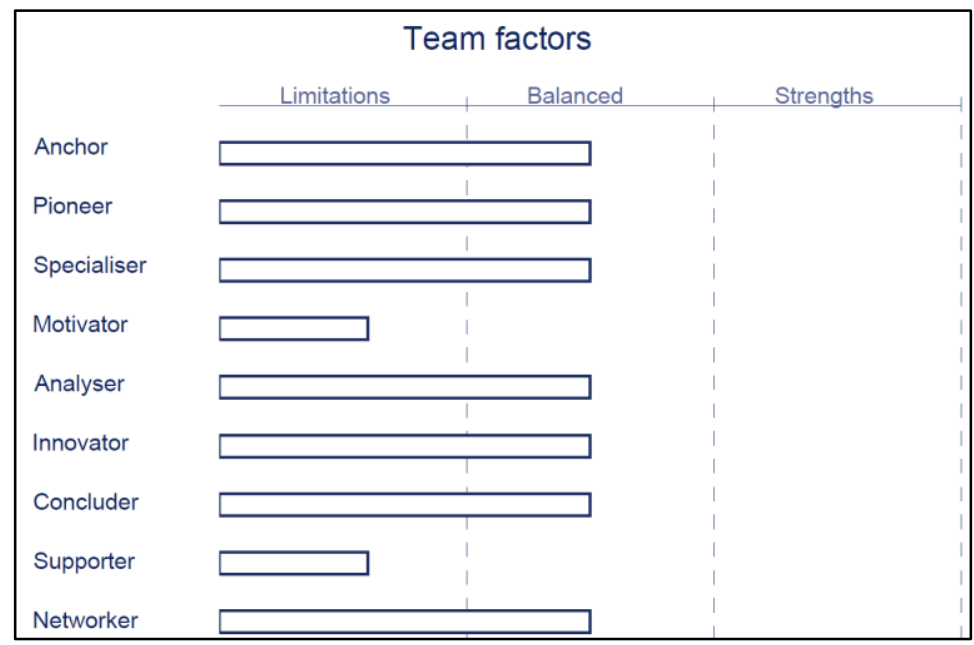

Figure 5: Executive personality analysis

It is evident that this specific team is well-balanced, with the ability to run the company successfully, as it is being run today. It contains the following team strengths:

- Working towards finding a satisfactory solution to all problems

- It is focused, and will push itself and others to reach goals

- It is good at communicating logical and analytical information to others

- It works towards a culture that achieves results through people, while maintaining high quality and standards

- It is willing to act and make decisions once accurate data and necessary facts are available

Current performance management practices at Master Drilling consist of the head-of-department having a performance evaluation criterion that matches the goals that the department is required to reach. These goals align with the company's overall strategy. When faring poorly in any of the predetermined goals, a skills gap is identified in the department, after which an investigation is launched to determine the root cause of the problem, and how it is going to be improved. These problems can be various things, such as a lack of training, language barriers, overuse of employees, unclear job expectations, etc. Each employee has a performance evaluation criterion that is 
designed to form a part of the function that is expected to be completed by the department. This relates to the research as summarised in Fig. 2.

However, performance management should not focus solely on the employee, but also on the gap (in the department or business unit) that is an underlying result of underperformance, for whatever reason. The identified areas are referred to as either areas of weakness or areas of potential, depending on the result of the evaluation. Well-faring areas are referred to as areas of potential, while the lesser areas are referred to as areas of weakness. For this gap to be bridged effectively, the company should aim to set and reach the correct goals to increase its Industry 4.0 maturity in all areas that it strategically aligns with its Industry 4.0 strategy. The company's employees are rated as a level 4 maturity, meaning that the workforce is competent to bridge the gap to Industry 4.0. In this case, it is referred to as an area of potential. This is a strength that the company could use to improve areas of weakness and to transform them into areas of potential. Department goals are thus set in the light of the Industry 4.0 maturity of each IMPULS dimension. If done correctly, the practices already in place to manage the current skill gaps can be used to manage the effective maturing of each dimension. It is very important to note that the employees form an integral role in Industry 4.0 adaptation in any company, as it is the employees who are to develop and implement the ways in which the Industry 4.0 maturity is to increase. Value can be added to employee initiatives when efforts are incentivised.

\subsubsection{Smart operations}

This can be loosely defined as the use of applications, such as information systems, wireless monitoring, field service management, cloud use, autonomous processes, and IT security, effectively to provide visibility using information and data processing to create more predictable and autonomous operations [32]. It uses Industry 4.0 technologies to create the ability to manage very complex supply chains with ease.

Master Drilling challenges conventional drilling methods, and constantly seeks to improve or innovate drilling practices to improve utilisation and drill speed, reduce expenses, and reduce the time in which drilling projects of any kind are completed. The company recently released a revolutionary, mostly autonomous, mobile tunnel bore (MTB) that can expand mines many times faster than any current conventional methods [33]. This technology makes use of a combination of loT, machine automation, and some big data principles to deliver this service.

The MTB is not the only technology in the company's development pipeline that is bridging the technology gap from manual to automated. Current raiseboring practices are being developed to a more autonomous state, and to be remotely controlled. When aligning the company strategy and goals, the use of smart operations not only adds increasing value to current operations, it also creates the potential for added value propositions to emerge in the company. Reducing complexities in operations and supply chains can create better use of company resources by removing unnecessary steps from the process [32]. Smart operations decrease the risks associated with employees working underground, and increase employee productivity.

\subsection{SWOT and TOWS analysis}

Master Drilling's strategy is to deliver specialised and adaptive drilling solutions to its customers [7]. To understand better the situation and context of Master Drilling, and the Industry 4.0 applications, a TOWS analysis was performed. This consists of a matrix revealing four different strategies:

1. Strengths used to maximise opportunities: 'Maxi-Maxi' strategy

2. Strengths used to minimise threats: 'Maxi-Mini' strategy

3. Taking advantages of opportunities to minimise weaknesses: 'Mini-Maxi' strategy

4. Minimising weaknesses while avoiding threats: 'Mini-Mini' strategy

This approach uses the company's existing strengths and weaknesses as inputs, which in this case are identified by using the maturity indexing tools. Note that these strengths and weaknesses solely refer to the Industry 4.0 readiness of the company. 
Table 1: Industry 4.0 readiness: Strengths and weaknesses in Master Drilling

\begin{tabular}{|c|c|}
\hline Strengths & Weaknesses \\
\hline $\begin{array}{ll}- & \text { Employees } \\
- & \text { Smart operations }\end{array}$ & $\begin{array}{ll}\text { - } & \text { Strategy \& organisation } \\
\text { - } & \text { Data-driven services } \\
\text { - } & \text { Smart factory } \\
\text { - } & \text { Smart products } \\
\end{array}$ \\
\hline Opportunities & $\begin{array}{c}\text { Threats } \\
\end{array}$ \\
\hline $\begin{array}{ll}- & \text { VR technology } \\
\text { - } & \text { Automation technology } \\
\text { - } & \text { IoT }\end{array}$ & $\begin{array}{ll}\text { - } & \text { Data leakage } \\
\text { - } & \text { Natural disasters } \\
\text { - } & \text { Health \& safety incidents } \\
\text { - } & \text { Competitor gaining market advantage }\end{array}$ \\
\hline
\end{tabular}

The TOWS analysis is shown in Table 2. It is these technological advances in the company that create the opportunity to adopt Industry 4.0 initiatives better. Having the necessary skillsets in-house, the technology and processes are being developed to lay the foundation for the rest of the dimensions in the company that are still maturing with regard to Industry 4.0 readiness. This further emphasises the incorporation of Industry 4.0 initiatives in the company.

Table 2: TOWS analysis of Master Drilling for Industry 4.0

\begin{tabular}{|c|c|c|}
\hline & External threats (T) & External opportunities (0) \\
\hline $\begin{array}{l}\text { Internal } \\
\text { strengths (S) }\end{array}$ & $\begin{array}{l}\text { Maxi-Mini } \\
\text { Employee skills used to } \\
\text { maximise information } \\
\text { integrity and security } \\
\text { Smart operations increase } \\
\text { advantage over } \\
\text { competitors, decreasing } \\
\text { possibility of competitors } \\
\text { gaining market growth } \\
\text { (MTB, Automated drills) } \\
\text { Combination of employees } \\
\text { and smart operations } \\
\text { decreases the risk of safety } \\
\text { incidents on-site } \\
\text { Natural disasters can't be } \\
\text { avoided, but competent } \\
\text { employees can help } \\
\text { mitigate the risks and } \\
\text { effects associated with } \\
\text { them }\end{array}$ & $\begin{array}{l}\text { Maxi-Maxi } \\
\text { Create disruptive technologies } \\
\text { such as MTB with employee and } \\
\text { operational strengths } \\
\text { Increase global advantage by } \\
\text { developing new technologies and } \\
\text { automating drill machines } \\
\text { Develop VR training methods to } \\
\text { improve safety practices in } \\
\text { company operations } \\
\text { Facilitate multiskilling of } \\
\text { workers with better training } \\
\text { capabilities }\end{array}$ \\
\hline $\begin{array}{l}\text { Internal } \\
\text { weaknesses (W) }\end{array}$ & $\begin{array}{l}\text { Mini-Mini } \\
\text { Increase company's } \\
\text { Industry } 4.0 \text { strategy to } \\
\text { increase vision for future } \\
\text { technologies and initiatives } \\
\text { Better product designs and } \\
\text { manufacturing methods } \\
\text { lead to safer working } \\
\text { environments and } \\
\text { consistent outputs }\end{array}$ & $\begin{array}{l}\text { Mini-Maxi } \\
\text { Use loT technologies on company } \\
\text { operations and exploration to } \\
\text { increase the data capabilities } \\
\text { and unlock potential business } \\
\text { cases from it } \\
\text { Automation technologies can } \\
\text { increase speed of production } \\
\text { when focused on developing a } \\
\text { smart factory and smart } \\
\text { products }\end{array}$ \\
\hline
\end{tabular}

\subsection{Towards a maturity improvement process}

A company looking to adapt to new Industry 4.0 initiatives should assess the need for the new technologies before simply starting to implement new initiatives. This will create a clear vision for which technologies should be focused on, and what value they will add to the company when implemented. 


\subsubsection{Analysis phase}

If new initiatives are needed, the current maturity of the company is to be determined with regard to certain dimensions. This can be done using one of many Industry 4.0 maturity index models. These models can be adjusted to an organisation's needs. In the case of Master Drilling, an existing maturity process was used. Customised maturity models can be used, but they must have a dimension-based framework to work successfully when following this process.

\subsubsection{Maturity improvement phase}

The dimensions for which the maturity is evaluated can be focused on either collectively or independently. One can thus either focus all resources on one specific dimension to improve it, or tackle numerous dimensions with the goal of collectively improving overall company maturity. This is, however, only advised when sufficient resources are available. It is advisable, firstly, to place sufficient focus on the dimensions that are low in maturity and on those that will create more value for the company. This is very similar to critical chain theory [34], except that the process aims to use the company's strengths better to influence and improve its weaknesses.

Action plans should be developed successfully to improve the dimensions that are focused on. These action plans will be company-specific and dimension-specific, as they will depend on the exact environment in which the dimension is to be improved. It should also be noted that some companies will adopt certain initiatives and action plans in the same dimension at different speeds, as their company cultures and priorities differ.

The action plans must then be successfully implemented, after which the resulting implementation needs to be evaluated. This evaluation confirms whether the Industry 4.0 need was in fact addressed properly, validating the solution. The results of the action plans are critical to capture, as their evaluation will reveal whether the company's maturity has in fact been increased through the implementation of these action plans.

\subsubsection{Contribution phase}

The resulting technology or initiatives can then be deployed in the applicable sector. This will create potential in the industry to improve, which in turn creates new opportunities for companies in the sector.

The method followed throughout this study delivered the successful identification of both areas of weakness and areas of potential in Master Drilling. The resulting information, if applied correctly, enables the company to identify improvement opportunities and which strengths could be used better to develop them. A maturity improvement process is developed, and is shown in Fig. 6 . This process can be replicated in any organisation to understand better and improve its maturity with regard to any specified dimensions.

\section{CONCLUDING REMARKS}

\subsection{Future research}

The mining sector in South Africa holds vast potential for productivity and technological improvements. These can be made effectively if the dimensions are individually approached for improvement. The sector can really benefit from an in-depth analysis on how each of the dimensions, listed by the IMPULS readiness self-check analysis, can be approached to become more mature. This will enable a company not only to identify its areas of weakness and potential, but also to provide the necessary action plan or roadmap for improvement. More research efforts can be aimed at new opportunities being created in industry when new technologies are implemented. Further value could be created if the focus of this study shifted to all sectors in the South African industry, for the country to adapt to the ever-changing nature of global industries.

This article forms a part of a master's study aimed at improving the maturity of a company with regard to Industry 4.0. The study will focus on the effect of new technologies and initiatives in the mining sector by using Master Drilling as a case study. The company itself is increasingly adopting new technologies and expanding its value offering by doing so. 


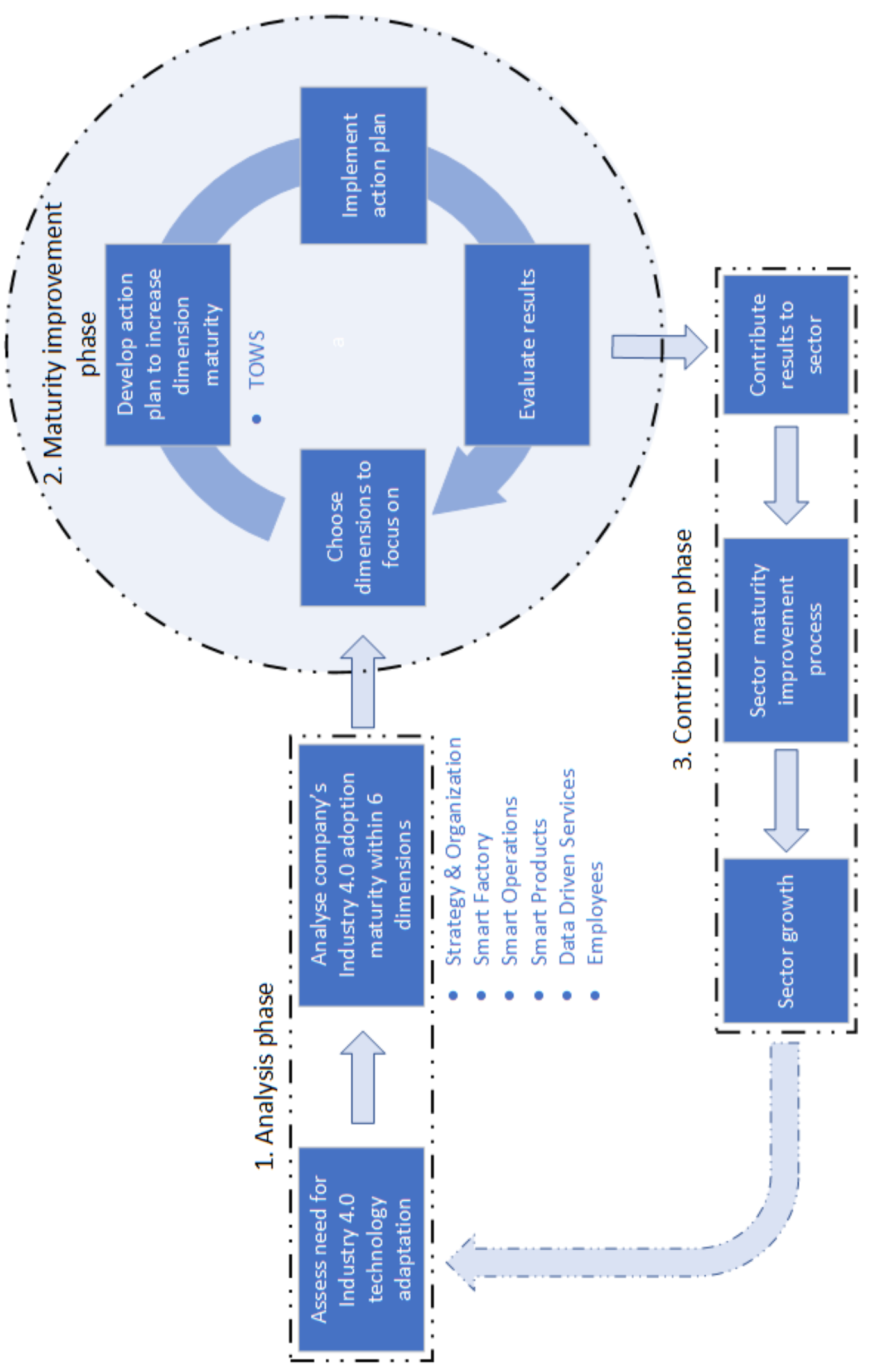

Figure 6: Company maturity improvement process 


\subsection{Note on sector readiness}

Mines in South Africa are facing constant challenges to become more productive, including an increase in haul distances, lower ore grades, increased expenditure, and decreasing improvement opportunities with conventional ways of thinking. The productivity of the mining sector has decreased over the past decade, shifting the sector's focus to incorporating more Industry 4.0 technology innovations, with the goal of both saving costs and reversing productivity losses.

The ability to capture vast amounts of data is becoming more affordable, while the skills in technology improvements are also increasing exponentially. All the potential exists for improvement - but it requires a proper mind shift away from conventional methods to incorporate the technological advancements found in industry today.

However, many challenges face the South African mining sector. Because of its complexity, a simplified approach is taken to evaluating the Industry 4.0 readiness of the sector itself - that is, by focusing on the Industry 4.0 maturity of Master Drilling, a company in the sector. The underlying challenges in the company will likely correlate with those found in the rest of the sector, as a case study is done on a company that aims to challenge the global status quo about its operational practices.

\subsection{Conclusion}

The use of technology in a corporate environment has revolutionised business models and practices for many years. New innovations can lead to gains in efficiencies, use of man and material, safety capabilities, and profitability if incorporated correctly into the current business structure. As seen with Master Drilling, the correct focusing of a company's strengths can benefit the maturing dimensions that are still in their infancy in respect of Industry 4.0. The development and acquisition of new skills is increasingly growing in importance in the mining sector, and is required for the technological advances that are likely in the future [35].

This revolution has the potential to change how mining in the South African context is approached, extracting the potential already residing in it. It is, however, a collective approach to industrialisation that creates a quicker adoption of Industry 4.0 in an entire sector. Not only Master Drilling, but all companies, will benefit from the maturity analysis and the development of action plans to bring the country back on a par with its global competitors.

\section{REFERENCES}

[1] Ashton, T.S. 1994. The Industrial Revolution 1760-1830, Economic Weekly, p. 16.

[2] Vaidya, S., Ambad, P. and Bhosle, S. 2018. Industry 4.0: A glimpse. Procedia Manufacturing, vol. 20, pp. 233-238.

[3] Schumacher, A., Erol, S. and Sihn, W. 2016. A maturity model for assessing Industry 4.0 readiness and maturity of manufacturing enterprises. Procedia CIRP, vol. 52, pp. 161-166.

[4] Pillay, K. 2017. Industry 4.0: Is Africa ready for digital transformation? Deloitte.

[5] StatsSA. 2017. Mining: A brief history. [Online]. Available: http: //www.statssa.gov.za/?p=9720. [Accessed 18 April 2018].

[6] Kotze, M. and Russouw, A. 2017. Mine SA, 9th edition, PWC.

[7] Master Drilling. 2017. The business: Master Drilling [Online]. Available: https://masterdrilling.com/us.html. [Accessed 18 April 2018].

[8] Kobayashi, I. 1990. 20 keys to workplace improvement. Florida: CRC Press.

[9] I. F. o. t. G. E. Federation. IMPULS Industry 4.0 Readiness online self-check for businesses. IMPULS [Online]. Available: https://www.industrie40-readiness.de/?lang=en. [Accessed 23 April 2018].

[10] Hagel, J., Brown, J.S., Samoylova, T. and Lui, M. 2013. From exponential technologies. Deloitte University Press.

[11] Chui, M., Loffler, M. and Roberts, R. 2010. The Internet of Things. McKinsey Quarterley, March.

[12] Hard-Line. 2018. Company overview. [Online]. Available: http://www.hard-line.com/company/. [Accessed 24 May 2018].

[13] Talk IoT. 2018. IoT can protect mining jobs. [Online]. Available: https://talkiot.co.za/2018/01/29/iotcan-protect-mining-jobs/. [Accessed 24 May 2018].

[14] Chui, M., Manyika, J. and Miremadi, M. 2016. Where machines could replace humans-and where they can't (yet), McKinsey Quarterly, July.

[15] Chui, M., Manyika, J. and Miremadi, M. 2015. Four fundamentals of workplace automation, McKinsey Quarterley, November. 
[16] Manyika, J., Chui, M., Miremadi, M., Bughin, J., George, K., Willmott, P. and Dewhurst, M. 2017. Harnessing automation for a future that works, McKinsey Quarterley, January.

[17] Moore, P. 2018. Mastering the turnaround - German technology. International Mining, vol. 13, no. 3, p. 10.

[18] Torrecilla, J. and Romo, J. 2018. Data learning from big data. Statistics and Probability Letters, pp. 1-5.

[19] Dhawan, A., Brand, J., Rossi, M. and Lubowitz, J. 2018. Big data: Progress or a big headache? Arthroscopy: The Journal of Arthroscopic \& Related Surgery, vol. 34, no. 3, pp. 649-651.

[20] Davenport, T. 2014. How strategists use big data to support internal business decisions, discovery and production. Strategy and Leadership, vol. 42, no. 4, pp. 45-50.

[21] Dingo. 2018. Dingo at a glance. [Online]. Available: http://www.dingo.com/company/dingo-at-a-glance. [Accessed 24 May 2018].

[22] Huang, T.-K., Yang, C.-H., Hsieh, Y.-H., Wang, J.-C. and Hung, C.-C. 2018. Augmented reality (AR) and virtual reality (VR). Kaohsiung Journal of Medical Sciences, vol. 34, no. 4, pp. 243-248.

[23] Solomons, I. 2015. Virtual reality technologies gaining traction in South African mining sector. Mining Weekly. [Online]. Available: http://www.miningweekly.com/article/virtual-and-augmented-realityincreasingly-valuable-to-mining-industry-local-uptake-growing-2015-11-13. [Accessed 24 May 2018].

[24] Moore, P. 2018. Disruptions new and old - Canadian technology. International Mining, vol. 13, no. 4, p. 24.

[25] Weber, C., Konigsberger, J., Kassner, L. and Mitschang, B. 2017. M2DDM - A maturity model for datadriven manufacturing. Procedia CIRP, vol. 63, pp. 173-178.

[26] Schuh, G., Anderl, R., Gausemeier, J., t. Hompel, M. and Wahlster, W. 2017. Industrie 4.0 - Managing the digital transformation of companies. Acatech: Munich.

[27] Zandin, K.B. 2001. Performance management: A key role for supervisors and team leaders, in Maynard's Industrial Engineering Handbook, fifth ed. New York: McGraw-Hill.

[28] Preis, E. and Webber-Youngman, R. 2017. Investigating the stage-gate model as a research and development implementation process in modernising the mining industry. Pretoria: University of Pretoria.

[29] Lichtblau, D.K., Stich, P.V., Bertenrath, D.R., Blum, M., Bleider, M., Millack, A., Schmitt, K., Schmitz, E. and Schröter, M. 2015. Industrie 4.0 readiness. Cologne: VDMA.

[30] Marston, W.M. 1928. Emotions of normal people.

[31] T. International, PPA. Thomas International, 2018. [Online]. Available: https: / /www.thomasinternational.net/en-za/assessments/assessments-we-offer/ppa/. [Accessed 10 June 2018].

[32] O'Marah, K. 2017. Smart operations and the Internet of Things - Digital impacts on business strategy. SCM World.

[33] Moore, P. 2018. Flexible tunneling in mines. International Mining, vol. 13, no. 5, pp. 50-51.

[34] Bergland, E. 2016. High-level critical chain review, in Get it done on time! A critical chain project management/theory of constraints novel. California, pp. 5-7.

[35] Preis, E. and Darwish, H. 2016. A revitalised \& sustainable socio-economic model for South Africa's mining communities. [Online]. Available:

https://www.researchgate.net/publication/313506437_A_Revitalised_Sustainable_SocioEconomic_Model_for_South_Africa\%27s_Mining_Communities. [Accessed 1 June 2018].

[36] Petrarolo, D. 1997. Benchmarking organisational capability using the 20 keys. South African Journal of Industrial Engineering, vol. 8, no. 2, pp. 16-32.

[37] Kotze, M. and Rossouw, A. 2018. South Africa's mining landscape. SA Mine, vol. 9, p. 5.

[38] Master Drilling. 2015. Master Drilling - The business [Online]. Available: https: / /masterdrilling.com/company-profile.html. [Accessed 4 June 2018]. 